\section{Delayed again}

The Council of Foreign Ministers of the European Economic Community (EEC) met in Brussels last week. Down for decision was the disputed site of the Community's fusion project, the Joint European Torus (JET). Chris Sherwell reports

Heads of government may make history, but in the EEC they don't appear to determine it. At their meeting in London at the end of June, they insisted that the Council of Foreign Ministers should decide the site for JET at its next meeting. In the event the Council failed to agree. And a research ministers meeting set for two days later was cancelled.

Although the UK Foreign Secretary, Dr David Owen, said last week that he was "very disappointed" by the "nondecision", British newspapers had carried well-briefed reports on the day the meeting started warning that no decision could be expected. This did not apparently contradict earlier reports of a majority in favour of Culham: the majority remained, but only belatedly was it realised that West Germany was sufficiently committed to Garching not to want the embarrassment of an immediate climb-down.

The majority itself was a change from the dark days in March when Culham, or rather Britain, fell from grace. Since then Britain has made some conciliatory gestures. notably in removing her reserve on the EEC's joint research programme, which have helped to restore the site to favour. Britain has also changed tack in her arguments, giving greater emphasis to her concern over the lack of any Community research project in the country (Germany has three) while at the same time acknowledging, that Garching is scientifically as suitable a centre to take JET as Culham.

But equally the West Germans have clung tenaciously to Garching. In Britain this is seen in straight political terms: Garching is in what is called 'Strauss country', a reference to the powerful leader of the Bavarian Christian Socialist Union whose influence on notentially shifting political coalitions is so great. An alternative view, that the Germans entertain worries about a Community nroiect going to Britain when the Labour Party is shaping up once more for internal combat over the FEC. is dismissed: it is said that the West Germans know from experience not to doubt the commitment to the EEC of Labour's leaders. Certainly if this was an important factor, it might have been expected to have caused problems across a far broader Community front than just JET.

Not that JET is unimportant. The foreign ministers have now removed the subject almost totally from the hands of the research ministers, whose meeting last week was arranged mainly to clear up loose ends once a decision was taken. But the foreign ministers still only considered the subject informally. Their new president, Henri Simonet, himself a former EEC Energy Commissioner and now Belgium's foreign minister, spoke individually to ministers, taking his own private poll. The subject was then discussed over lunch.

No vote was taken, but it did emerge that if JET was not to go to Culham, it might not go anywhere-a possibility reportedly canvassed by the French, whose own fusion research (notably on Torus (I) has been held up by the indecision over JET. Equally, however, if a vote was taken, it would apparently have gone in favour of Culham. One report had it that four countries favoured Culham, two favoured Garching, two were prepared to go with the majority, and one did not pronounce. But that accounting is probably only a 'guesstimate', at best.

Most affected is the JET team itself, based at Culham. Indeed, the lack of a decision is all the more surprising for the fact that the head of the comparable fusion project at Princeton in the United States sent a telegram ahead of the meeting to Paul Rebut, head of the JET team, and Donato Palumbo, director of the EEC fusion programme. The telegram in effect expressed horror at the possibility that JET might not go through and that Europe might not recognise its responsibilities; if JET did not go ahead, it inquired, how many of the team would consider working on the PFTR nroiect at Princeton?

Dr Owen's appeal to the JET team to stay on at Culham, which came after the meeting, was probably made with a eve hoth to this and to the start of the next school year. Some of the team are thought to have already begun arranging schooling for their children in their own countries, not wishing to wait any longer for a 'final' decision. Their contracts have been extended once again, however, this time to the end of September.

By that time the Foreign ministers ought, with luck and the political will to have decided on a site. Another meeting is set for 20 September. Between now and then Simonet is expected to visit both I.ondon and Bonn to try to iron out the difficulties. His close and long standing relationship with the present Energy and Research Commissioner, Guido Brunner, is expected to help, and though a date has yet to be set, it is on the cards that the British and German heads of government and foreign ministers will meet in Germany for one of their regular hilateral gatherings, the last of which was in L.ondon earlier this year.

All will be seeking a way to reach full agreement; a mere majority vote is inadequate under the Community scheme which allows issues not to be decided whenever any single country believes that its national interest is involved. If agreement fails yet again to materialise, JET in its existing form will almost certainly die and Britain and France will probably start initiating their own respective schemes for some other sort of project on a bilateral or trilateral basis. The British prime minister warned of this possibility after the heads of government meeting in June, and there has since been talk in similar terms in both France and Germany.

For the moment the presumption remains that they still wish to cooperate with each other. and to do so through to the Community. It is a presumption increasingly undermined by experience.

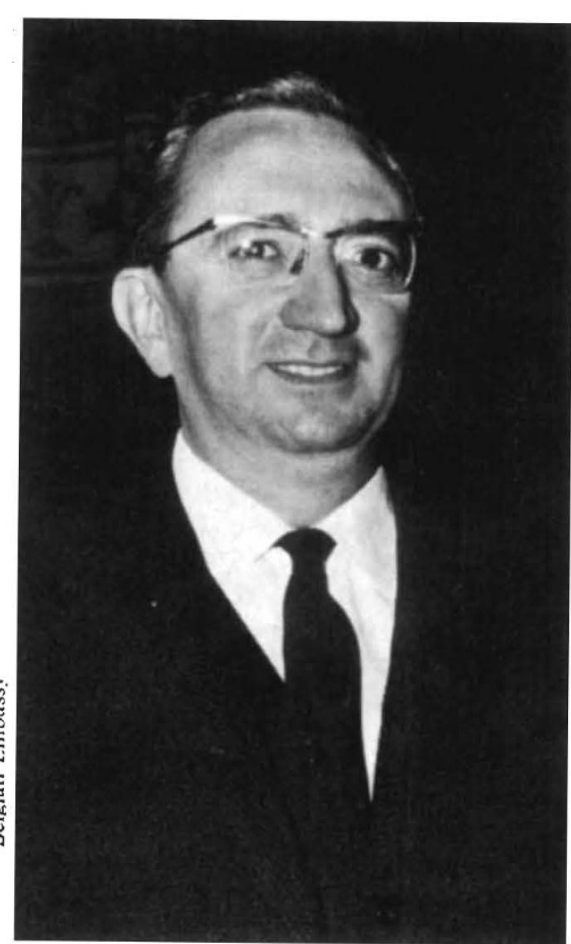

Henri Simonet 